\title{
KELIMPAHAN INVERTEBRATA DI PULAU SEMPU SEBAGAI INDEKS BIOINDIKATOR, EKONOMIS PENTING KONSUMSI, DAN KOMODITAS KOLEKSI AKUARIUM
}

\author{
Oktiyas Muzaky Luthfi ${ }^{\mathrm{a} * *}$, Citra Satrya Utama Dewi ${ }^{\mathrm{a}}$, Respati Dwi Sasmitha ${ }^{\mathrm{a}}$, Dimas Syarif Alim ${ }^{\mathrm{a}}$, \\ Dimas Bagus Dwi Putranto ${ }^{a}$, Firly Yulianto ${ }^{a}$
}

${ }^{a}$ Ilmu Kelautan, Fakultas Perikanan dan Ilmu Kelautan, Universitas Brawijaya, Jalan Veteran, Kota Malang, Jawa Timur 65145, Indonesia

*Corresponding author: omuzakyl@ub.ac.id

\begin{abstract}
Abstrak
Invertebrata (Hewan tak bertulang belakang) mempunyai beberapa peran penting untuk perairan dan ekosistem terumbu karang, baik sebagai bioindikator, ekonomis penting, atau diambil sebagai penghias akuarium. Sebagai contoh bulu seribu (Acanthaster planci) merupakan hewan yang terkenal akan kemampuannya melakukan predasi pada jaringan karang, dan bulu babi (Diadema sp) yang dapat melakukan grazing pada alga di ekosistem terumbu karang. Penelitian ini mempunyai tujuan yaitu mengetahui kelimpahan Invertebrata dan hubungannya dengan indeks bioindikator, ekonomis konsumsi, dan komoditas koleksi. Pengamatan dilakukan Pulau Sempu dibagi menjadi beberapa stasiun, diantaranya Teluk Semut 1, Teluk Semut 2 dan Watu Meja. Pendataan hewan invertebrata di lokasi pengambilan data menggunakan metode Reef Check dengan cara menggelar belt transect sepanjang $100 \mathrm{~m}$ yang terbagi menjadi 4 segment sepanjang $20 \mathrm{~m}$. Pengamatan dan pengambilan data dilakukan secara zig-zag sehingga data yang dihasilkan lebih lengkap dan dapat mempresentasikan persebaran invertebrata yang ada di setiap stasiun di perairan pulau sempu. Hasil pendataan dari ketiga stasiun ini terdapat sebanyak 1 ekor Banded Coral Shrimp, 2 ekor Diadema urchin, 1 ekor Pencil urchin, 1 ekor Colector Urchin, dan 1 buah Giant clam dengan besar 10-20 $\mathrm{cm}$. Sedikitnya jumlah kelimpahan invertebrata berbanding lurus dengan kondisi terumbu karang yang ada di perairan selat sempu. Beberapa hewan invertebrata yang ditemukan dapat dikonsumsi atau dijual dan menjadi mata pencaharian alternatif selain menangkap dan budidaya ikan. Secara ekologi keberadaan avertebrata laut di Pulau Sempu berperan sebagai salah satu alat biomonitoring kondisi dan kesehatan terumbu karang diperairan tersebut.
\end{abstract}

Kata Kunci: Bio-indokator, Ekonomi Penting, Invertebrata, Pulau Sempu, Reef Check

\begin{abstract}
Invertebrates have several important roles for coral reef ecosystems, either as bioindicators, economically important, or taken as decorative aquariums. For example, Acanthaster planci is an animal known for its ability to predate coral tissue, and Diadema sp that can graze on the algae in coral reef ecosystems. The aim of this study was to know the abundances of coral invertebrates and its connection to bioindicators, commercial importances, and collection commodities indexes. Sempu Island observations were divided into 3 sites, including Teluk Semut 1, Teluk Semut 2 and Watu Meja. Invertebrate data collection at location was conducted using Reef Check method by rolling out belt transect along $100 \mathrm{~m}$ which was divided into 4 segments with length of $20 \mathrm{~m}$ each. Observation and retrieval of the data was done jagged diagonally to produce more complete and representative distribution of invertebrates that exist in every stations in the waters of Sempu Island. The data collected from these three stations were 1 Banded Coral Shrimp, 2 Diadema urchin, 1 Pencil urchin, 1 Colector Urchin, and 1 Giant clam with 10-20 cm in size. Low number of invertebrate abundances was related to the condition of coral reefs in the waters of the sempu strait. Several invertebrates observed can be consumed or sold and become alternative livelihoods other than catching and cultivating fish. In ecological view the role of invertebrate in Sempu Island was very important for indicating the condition and health of coral reef in that location.
\end{abstract}

Keywords: Bio-indocators, Economics Important, Invertebrates, Reef Check, Sempu Island 


\section{PENDAHULUAN}

Invertebrata merupakan kelompok binatang yang tidak mempunyai tulang belakang (vertebrae) [1]. Invertebrata, mencakup 95\% dari semua jenis hewan yang telah diidentifikasi, merupakan hewan yang persebarannya paling luas dengan keunikan setiap ekosistem [2]. Invertebrata digunakan sebagai bioindikator karena mempunyai sifat hidup yang relatif menetap dalam jangka waktu yang lama, sifat infertebrata tersebut yang memungkinkan untuk merekam kualitas suatu perairan. Invertebrata terbagi kedalam beberapa filum yaitu: Arthropoda; Mollusca; Echinodermata; Annelida; Polifera; Coelenterata; Nemathelminthes; dan Platyhelminthes [1]. Di Indonesia, kurang lebih terdapat 1.800 spesies yang termasuk ke dalam filum Invertebrata [3]. Karakteristik biota indikator pencemaran adalah: mudah diidentifikasi; mudah diambil untuk dijadikan sampel; pola distribusi biota kosmopolitan; mudah menyerap atau penyimpan bahan pencemar; dan peka terhadap perubahan lingkungan.

Kadar pencemar fisika kimia dalam ekosistem perairan dapat menyebabkan turunnya diversitas hewan invertebrate [4]. Kelimpahan jumlah invertebrata di suatu perairan sangat dipengaruhi oleh beberapa faktor kimia dan fisika yang terdapat pada lingkungan tersebut. Beberapa faktor yang mempengaruhi diantaranya adalah suhu, kuat arus, $\mathrm{pH}$ dan terjadinya runoff sungai yang membawa beberapa bahan kimia yang dihasilkan dari daratan. Semakin banyak bahan kimia yang mencemari lingkungan, maka semakin sedikit organisme yang dapat hidup atau toleran di lingkungan perairan tersebut.

Invertebrata mempunyai tiga aspek fungsi dalam lingkungan yaitu sebagai bioindikator, ekonomi penting konsumsi, dan komoditas koleksi. Invertebrata bioindikator merupakan biota yang mempunyai pengaruh langsung ke lingkungan. Invertebrata bioindikator yang termasuk pada pemantauan ini adalah Banded Coral Shrimp (Stenopus hispidus), Diadema urchin (Diadema antillarum), Crown of Thorns/ COTs
(Acanthaster planci) (Gambar 5.h), Kima (Tridacna sp.), dan Teripang (Thelenota ananas) (Gambar 5.e). Invertebrata juga dapat dilihat indeks ekonomi penting konsumsi, antara lain: lobster (Panulirus versicolor) (Gambar 5.i) dan teripang (Gambar 5.f dan 5.g). Invertebrata komoditas koleksi akuatis umumnya dicari untuk penghias akuarium air laut. Invertebrata koleksi akuatis yang diamati adalah Banded Coral Shrimp (Stenopus hispidus), Collector urchin (Tripneustes sp.), dan Pencil urchin (Heterocentrotus spp.). Banded Coral Shrimp merupakan spesies yang popular diantara kolektor akuarium air asin. Hewan ini mempunyai warna tubuh menarik dan dapat membersihkan akuarium membuat hewan ini disukai banyak kolektor akuarium hias. Negara pengekspor terbesar hewan ini adalah Filipina dan Indonesia, dimana tingkat edukasi masih rendah sehingga mengandalkan ekspor hewan ini [5]. Diadema urchin merupakan hewan yang banyak dikonsumsi gonadnya oleh masyarakat pesisir. Masyarahat biasanya mengambil langsung di pantai ketika surut. Sekarang ini sudah banyak yang membudidayakan hewan ini untuk dijual [6]. Bulu babi menjadi hewan yang dikoleksi oleh kolektor akuarium air asin karena warnanya yang menarik. Umumnya spesies yang dipasarkan adalah spesies yang racunnya kurang kuat [7]. Acanthaster planci atau biasa disebut dengan hewan COTs yang dijadikan sebagai bioindikator predator karang [8]. Pencil urchin memiliki duri beracun tumpul dengan jumlah sedikit. Tidak seperti jenis urchin lain, Pencil urchin memiliki warna yang menarik dan beragam. Hal ini menjadikan Pencil urchin sebagai salah satu biota yang paling dicari untuk hiasan akuarium $[9 ; 10]$. Kima adalah salah satu dari banyak invertebrata laut yang dapat bersimbiosis dengan zooxanthellae. Hewan ini umumnya hidup di perairan tropis IndoPasifik [11]. Hewan ini unik karena ukurannya yang besar dan kebiasaan makan hewan ini yang menarik [12]. Giant clam mendapat nutrisi dengan empat cara: (1) autotrofik memanfaatkan fotosintesis dari zooxanthellae; (2) memakan zooxanthellae yang ada di tubuhnya; (3) filter feeder; dan (4) nutrisi dari bahan organik terlarut dan molekul 
inorganik. Maka dari itu, keberadaan hewan ini penting bagi perairan karena dapat menjadi indikator kesehatan ekosistem terumbu karang [13]. Jenis teripang Prickly Redfish (Thelenota ananas) merupakan teripang dengan nilai jual sedang. Thelenota ananas yang memiliki nama lokal teripang nenas, berukuran $35 \mathrm{~cm}$ dijual ke pengepul dengan harga 200 ribu perkilogram [14] [15]. Hewan ini juga dapat berfungsi sebagai antikoagulan dan berkhasiat sebagai penyembuh luka. Persebaran hewan ini berada di wilayah sub-Pasifik tropis [16]. Lobster (Panulirus versicolor) merupakan komoditas ekspor perikanan Indonesia. Hampir seluruh perairan pantai Indonesia merupakan penghasil lobster. Perairan dengan tingkat penghasilan paling tinggi adalah Cilacap [17]. Triton, terompet triton, hidup pada habitat pasir, dan merupakan predator alami dari COTs (Gambar 5.j). Keberadaan Triton selama ini dapat menjadi kontrol kelimpahan dari COTs yang ada di ekosistem terumbu karang. Sedangkan, cangkang Triton merupakan komoditas koleksi akuaria yang dijual untuk hiasan. Perburuan atau eksploitasi berlebih terhadap Triton akan berakibat meningkatnya jumlah COTs di ekosistem terumbu karang [18] [19]. Pulau Sempu yang memiliki luasan 877 ha memiliki luasan ekosistem terumbu karang sebesar $36 \%$ atau dalam kategori sedang yang terletak pada Selat Sempu [20].

Selat Sempu merupakan perairan yang tenang karena tertutupi oleh Pulau Sempu, di sebelah selatannya, sehingga memberikan keamanan kepada armada tangkap yang banyak beroperasi di sekitar kawasan tersebut [21]. Secara administratif, Selat Sempu masuk ke dalam wilayah Desa Sitiarjo yang berjarak $70 \mathrm{~km}$ dari pusat Kota Malang [20]. Banyak kegiatan perikanan tangkap dilakukan di selat ini, sehingga dapat dikatakan daerah ini sebagai penyangga perekonomian masyarakat sekitarnya. Selain itu daerah Selat Sempu memiliki potensi sumberdaya perairan yang perlu dikembangkan seperti ekosistem pantai, hutan mangrove, danau, berbagai macam ikan dan terumbu karang yang belum diketahui oleh banyak orang, dan berbagai kegiatan sosial ekonomi seperti Tempat Pelelangan Ikan (TPI), pelabuhan sandar kapal dan tempat pariwisata [22]. Tujuan dari penelitian ini adalah untuk mengetahui kelimpahan invertebrata di perairan Pulau Sempu dan melihat kaitannya dengan ketiga aspek indikator invertebrata, yaitu sebagai bioindikator, ekonomis penting konsumsi, dan komoditas koleksi.

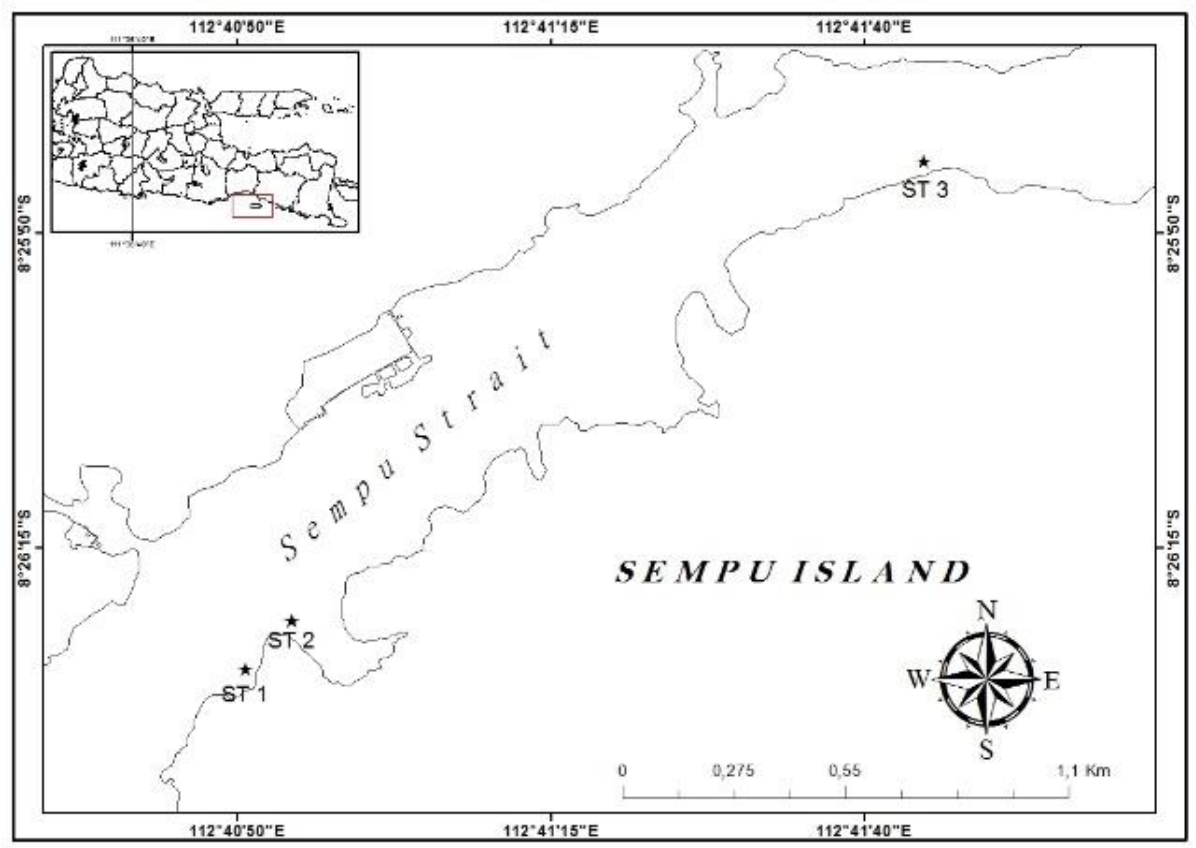

Gambar 1. Peta lokasi pengambilan data (ST 1: Teluk Semut 1; ST 2: Teluk Semu 2; ST 3: Watu Meja. 


\section{METODE}

Monitoring invertebrata dilaksanakan pada tanggal 8-9 Desember 2017 di perairan Selat Sempu, Malang Selatan. Pada hari pertama, dilakukan pemasangan transek permanen di tiga stasiun dilanjutkan pengambilan data invertebrata pada stasiun 2. Hari kedua dilakukan pengambilan data pada stasiun 3 dan stasiun 1 (Gambar 1). Data diambil dari tiga titik stasiun. Tiga titik stasiun dipilih berdasarkan lokasinya yang dianggap representatif mewakili kondisi terumbu karang Selat Sempu, seperti perbedaan lokasi secara geografis dan kecepatan arus serta adanya jalur kapal nelayan yang keluar masuk Selat Sempu. Terumbu karang banyak ditemukan diwilayah barat pulau sempu, sehingga kami melakukan penelitian di bagian barat pulau sempu. Juga arus yang mengalir di sisi timur selat sempu sangat kencang dan adanya out flow dari sungai sehingga perairan keruh.

Titik koordinat tiap stasiun dicatat menggunakan GPS dimana stasiun 1 adalah Teluk Semut 1 ( $8^{\circ} 26$ '25'LS dan $112^{\circ} 40^{\prime} 51$ ”'BT); stasiun 2 adalah Teluk Semut 2 ( $8^{\circ} 26^{\prime} 23^{\prime \prime} L S$ dan $112^{\circ} 40^{\prime} 53^{\prime \prime}$ BT) dan stasiun 3 adalah Watu Meja $\left(8^{\circ} 25^{\prime} 45^{\prime \prime} L S\right.$ dan $112^{\circ} 41^{\prime} 49^{\prime \prime B T) . ~ P e n g a m b i l a n ~ d a t a ~ t e l a h ~}$ dilaksanakan pada pagi hari dengan kisaran waktu pukul 08.00 - 14.00 WIB.

Pengambilan data invertebrata menggunakan transek sabuk 5 x $100 \mathrm{~m}$ (lebar $\mathrm{x}$ panjang) (ReefCheck.org), sehingga total luasan transek yang didapatkan pada setiap stasiun adalah sebesar $500 \mathrm{~m}^{2}$ (Gambar 2). Pengambilan data dilakukan mengggunakan alat penyelaman (Scuba set) yang terdiri dari tabung selam, regulator, BCD, masker, dan fins. Data diambil pada 2,5 m sebelah kiri dan kanan line transect dimana invertebrata yang ditemukan kemudian dicatat jenisnya dan dihitung jumlahnya. Selain dilakukan pencatatan secara manual, pengambilan data juga menggunakan kamera bawah air Canon G 16 (Jepang).

Khusus pengambilan data Giant clam, dilengkapi dengan pengukuran data cangkang. Pengukuran dilakukan menggunakan sabak yang sudah dilengkapi skala yaitu mengukur lebar cangkang (anterior-posterior) serta tingginya (dorso-ventral) [23].

Kelimpahan biota pada masing-masing transek dihitung dengan rumus kelimpahan [24] sebagai berikut :

Kelimpahan $=\frac{\text { Jumlah Biota }}{\text { Luas Area }\left(100 \mathrm{~m}^{2}\right)}$

Nilai komposisi per-jenis invertebrata dihitung dengan rumus sebagai berikut :

lenis ke $-i=\frac{\text { Biota Jenis ke }-i}{\text { Kelimpahan Total }} \times 100 \%$

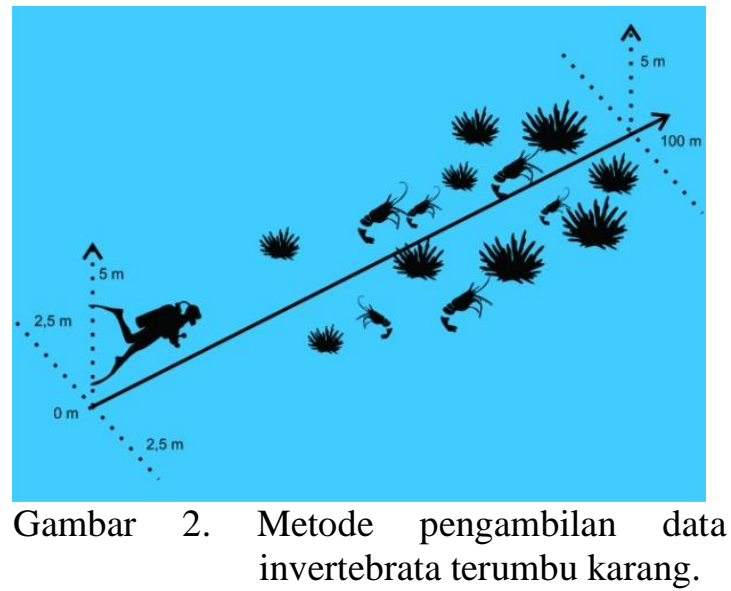

\section{HASIL DAN PEMBAHASAN}

Ketiga stasiun penelitian berada di utara Pulau Sempu yang merupakan perairan dengan arus yang lemah, dimana menurut [24], ambang batas arus lemah adalah 0-4 m/s. Arus secara umum di tiga lokasi penelitian dipengaruhi monsoon barat dan timur dengan kecepatan rerata adalah $0,3-0,6 \mathrm{~m} / \mathrm{s}$ [25]. Arus yang deras (kecepatan 8-12 m/detik) dapat mengaduk sedimen yang berada di dasar perairan, sehingga nilai turbiditas perairan akan sangat tinggi. Berdasarkan [25], nilai turbiditas di perairan Selat Sempu ini berkisar antara 0,69-10,36 NTU.

Berdasarkan Gambar 3, tercatat 1 Diadema urchin ditemukan di Stasiun 1. Selain Diadema urchin dan tidak ditemukan biota indikator lain. Spesies yang ditemukan adalah Diadema antillarum (Gambar 5.b) merupakan biota herbivora pemakan alga. Hewan ini dianggap penting karena dia dapat memakan alga di terumbu yang menjadi 
kompetitor karang. Hewan ini menjadi kunci penting akan kelimpahan alga di lingkungan terumbu karang dimana hewan ini dapat melakukan predasi terhadap alga dan menjadikan kesehatan karang tetap terjaga [26; 27]. Berkurangnya jumlah Diadema urchin dapat menjadikan ekosistem terumbu karang menjadi banyak ditumbuhi alga [28]. Keberadaan Diadema urchin (makrozoobentos) di perairan dipengaruhi faktor fisika kimia di lingkungan tersebut. Faktor-faktor tersebut antara lain adalah suhu, kuat arus, $\mathrm{pH}$ dan juga bahan-bahan kimia [29]. Semakin banyak bahan pencemar lingkungan perairan, berarti semakin sedikit organisme yang toleran terhadap lingkungan tersebut. Hal ini berakibat pada menurunnya keragaman spesies pada lingkungan tersebut [30]. Diadema urchin juga merupakan biota yang bersifat ekonomis penting. Ada beberapa spesies yang banyak dikonsumsi oleh masyarakat Jepang, yaitu: Strongylocentrotus intermedius, Strongylocentrotus nudus, Hemwentrotus pulcherrimus, Anthocidaris crassispina, dan Pseudocentrotus depressus. Sebanyak 20.000 ton pertahun bulu babi dimakan oleh masyarakat Jepang [31]. Gonad bulu babi (Tripneustes gratilla) telah dimanfaatkan oleh masyarakat Nusa Penida dan Sanur sebagai bahan makanan dan biasanya bulu babi diambil pada surut terendah [32].

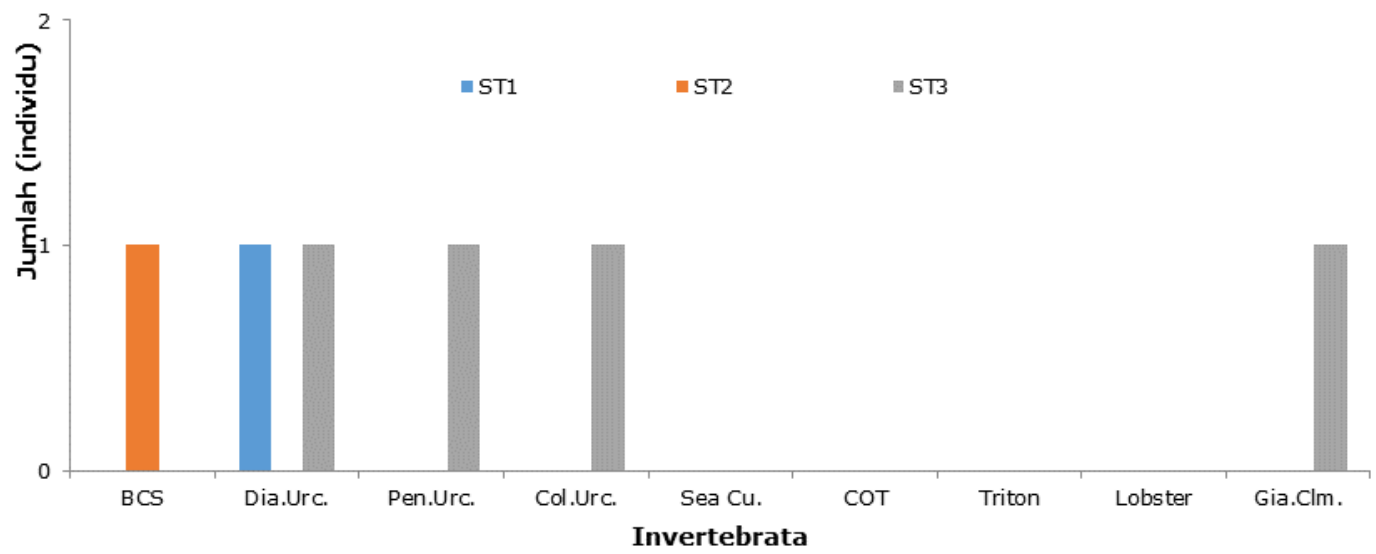

Gambar 1. Jumlah Invertebrata pada setiap stasiun. (BCS: Banded Coral Shrimp; Dia.Urc.: Diadema urchin; Pen.Urc.: Pencil urchin; Col.Urc.: Collector urchin; Sea Cu.: Sea cucumber; COT: CoTs; Gia.Clm.: Giant clam).

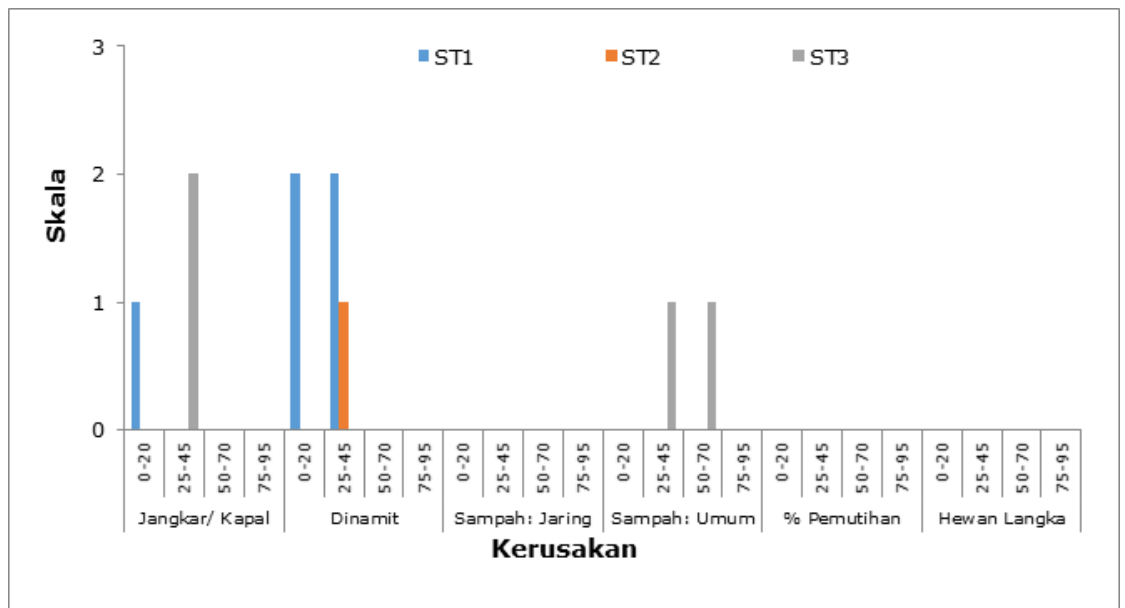

Gambar 2. Tingkat kerusakan karang dengan skala 1-3. (1: Rendah; 2: Sedang; 3: Tinggi) 
Berdasarkan hasil pengamatan/ observasi pada penelitian ini kerusakan karang pada Stasiun 1 disebabkan oleh jangkar kapal (Gambar 4). Ciri khas kerusakan karang akibat jangkar adalah koloni karang akan berubah menjadi kumpulan pecahan kecil (rubble) dengan bentuk memanjang (1-2 meter) [33]. Ada beberapa kegiatan manusia yang berakibat pada kerusakan ekosistem terumbu karang, baik langsung maupun tidak langsung kegiatan tersebut adalah: penambangan atau pengambilan karang; penangkapan ikan dengan alat tangkap tidak ramah lingkungan (bahan peledak, racun, bubu, jaring, pancing, dan eksploitasi berlebihan); pemasukan bahan pencemaran (minyak bumi, limbah industri, dan rumah tangga); dan pengembangan daerah wisata dan sedimentasi [34]. Beberapa penyebab kerusakan dari ekosistem perairan Pulau Sempu adalah pembangunan Pelabuhan Perikanan Nusantara di Sendang Biru pada tahun 2006-2009. Kegiatan ini menyebabkan penyebaran sedimen ke perairan sekitar dari proses reklamasi pantai seluas 2,6 $\mathrm{Ha}$. Penyebab lain yaitu pembuangan oli kapal nelayan ke perairan, penggunaan sianida, dan bertambahnya jumlah wisatawan yang datang [35].

Tabel 1. Kelimpahan Invertebrata

\begin{tabular}{cccc}
\hline \multirow{2}{*}{ Biota } & \multicolumn{3}{c}{ Kelimpahan Jenis } \\
\cline { 2 - 4 } & St. 1 & St. 2 & St. 3 \\
\hline BCS & 1 & 0 & 0 \\
Dia.Urc & 0 & 1 & 0.25 \\
Pen.Urc & 0 & 0 & 0.25 \\
Col.Urc & 0 & 0 & 0.25 \\
Sea.Cu & 0 & 0 & 0 \\
COT & 0 & 0 & 0 \\
Tri & 0 & 0 & 0 \\
Lob & 0 & 0 & 0 \\
Gia. Cla & 0 & 0 & 0.25 \\
\hline Kelimpahan & 0.002 & 0.002 & 0.008 \\
\hline
\end{tabular}

Satu Banded Coral Shrimp (Gambar 5.a) ditemukan di Stasiun 2 (Teluk Semut 2) (pada transek 0-20 m). Banded Coral Shrimp (Stenopus hispidus) merupakan biota karang yang menjadi favorit kolektor akuarium air laut. Udang ini tersebar di Atlantik bagian tropis, Indopasifik dan Laut Merah. Hewan ini umumnya bersembunyi di sela-sela terumbu karang. Udang mempunyai karakteristik warna belang merah dan putih. Hewan ini dikenal sebagai udang pembersih ikan. Julukan ini didasarkan pada kemampuan Banded Coral Shrimp yang mampu menghilangkan parasit di ikan pada habitat alaminya [36]. Udang ini akan menggoyangkan antenanya sebagai tanda kepada ikan karang untuk mendekat dan dibersihkan [37]. Invertebrata dengan nilai kelimpahan paling tinggi pada Stasiun 1 adalah Banded Coral Shrimp dengan nilai kelimpahan 1. Nilai yang sama didapatkan pada Stasiun 2 yaitu biota Diadema urchin (Tabel 1).

Aktifitas yang dapat menyebabkan kerusakan terumbu karang secara fisik adalah kegiatan penyelaman, penambatan kapal dengan sistem jangkar, endapan pecahan karang di dalam sedimen dan pencemaran dari industri termasuk powerplant [38]. Kondisi kerusakan terumbu karang berdampak langsung terhadap hasil tangkapan nelayan tradisional dalam jangka waktu lima tahun [39]. Hal yang paling mendasari aktivitas perusakan terumbu karang adalah kurangnya tingkat pendidikan nelayan tradisional. Nelayan tradisional masih menganggap terumbu karang bukanlah aspek penting untuk ekonomi. Hal ini menimbulkan anggapan bahwa perusakan yang dilakukan tidak akan berpengaruh dalam jangka panjang. Anggapan yang salah ini dapat ditepis dengan dilakukannya pemerataan pendidikan bagi nelayan tradisional.

Invertebrata (indikator) yang ditemukan pada Stasiun 3 (Watu Meja) berjumlah paling banyak dibandingkan dengan stasiun lainnya. Pada transek ke-25 hingga $45 \mathrm{~m}$, ditemukan Collector urchin sebanyak satu ekor, transek ke-50 hingga $70 \mathrm{~m}$ ditemukan Diadema urchin, Pencil urchin, dan kima dengan ukuran 10-20 cm masing-masing sebanyak satu ekor (Gambar 3). Pencil urchin (Heterocentrotus spp.) mempunyai karakteristik duri pendek dan tebal (Gambar 5.c), warna hewan ini cenderung lebih cerah dibanding urchin lain. Invertebrata ini sering 
a.

c.

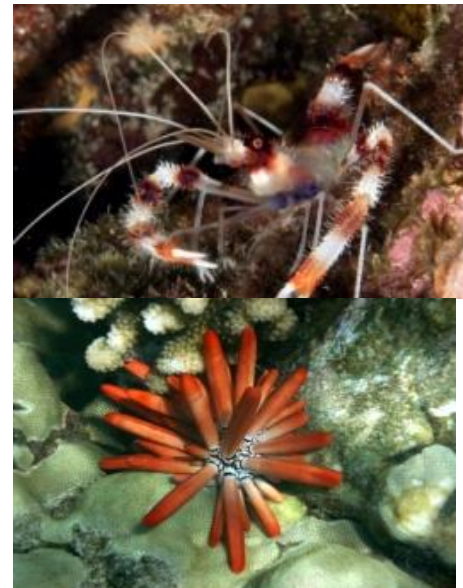

e.

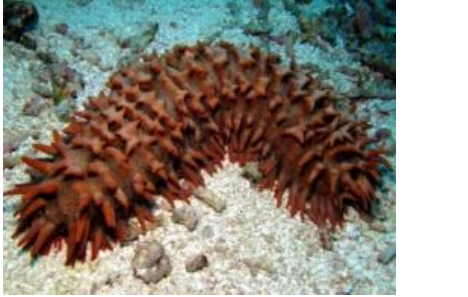

g.

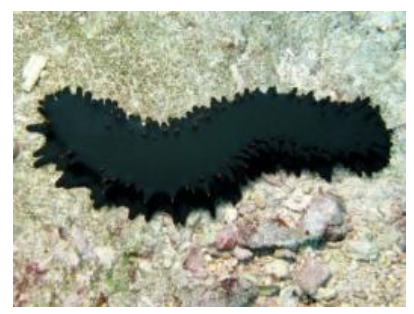

i.

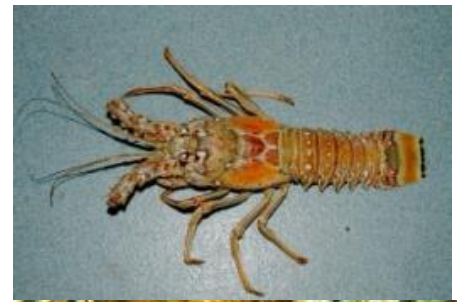

k.

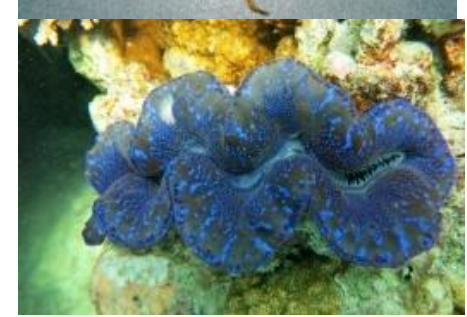

b.

d.

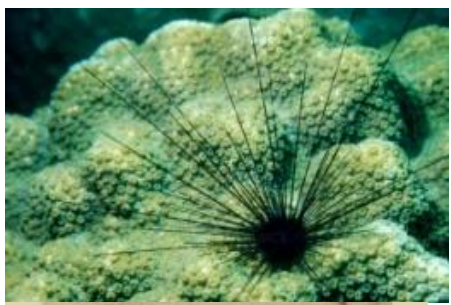

h.

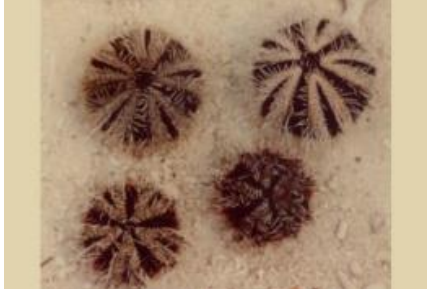

f.

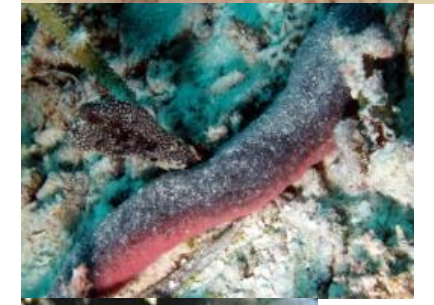

j.

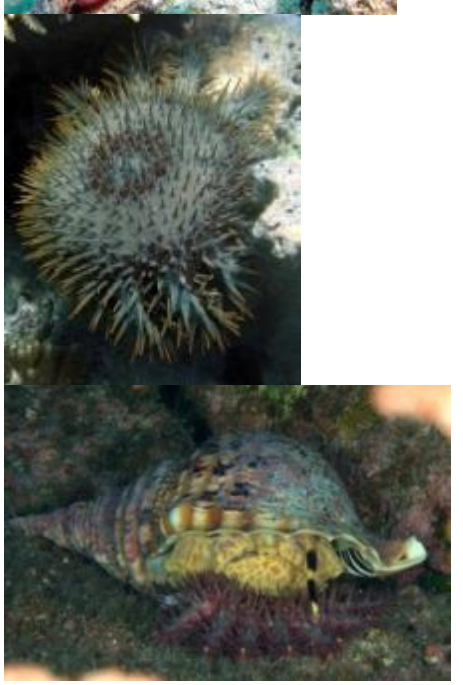

Gambar 3. Foto biota yang diamati (dari berbagai sumber). Keterangan gambar: (a) Banded Coral Shrimp/ Stenopus hispidus [40]; (b) Diadema urchin/ Diadema antillarum [41]; (c) Pencil urchin/ Eucidaris tribuloides [42]; (d) Collector urchin/ Tripneustes gratilla [43]; (e) Red Pickled Fish Sea Cucumberl Thelenota ananas [44]; (f) Pinkfish Sea Cucumberl Holothuria edulis [45]; (g) Greenfish Sea Cucumberl Stichopus chloronotus [46]; (h). COTs [47]; (i) Lobster/ Panulirus argus [48]; (j) Triton/ Charonia tritonis [49]; dan (k) Giant clam/ Tridacna maxima [50]. 
ditangkap sebagai hiasan akuarium air laut [10]. Pencil urchin merupakan hewan omnivore, dan memiliki kebiasaan bersembunyi diantara terumbu pada siang hari dan aktif pada malam hari [51]. Duri (spine) Pencil urchin bisa mencapai $15 \mathrm{~cm}$ dengan racun berada diujung durinya. Beberapa ikan memakan Pencil urchin dengan cara membalikan posisi bagian dorsal, sehingga tidak bisa bergerak dan mudah dimangsa [9]. Collector urchin (Tripneutes spp.) mempunyai habitat di dasar laut dengan kedalaman 2-30 m (Gambar 5.d). Ciri khas dari Pencil urchin adalah memiliki warna gelap dan duri pendek berwarna putih [52].

Kima adalah hewan dari filum moluska, kelas Pelecypoda, dan Ordo Tridacnidae dengan ciri khas membenamkan diri setengah ataupun seluruh cangkangnya pada karang (Gambar 5.k). Kima memiliki alga simbion yang disebut sebagai Zooxanthellae. Alga simbion ini tersebar pada jaringan khusus yang berada pada mulut cangkang kima, yang memberikan warna pada mulut cangkang kima dan dapat dilihat ketika posisi cangkang terbuka [53] [54]. Kima termasuk Invertebrata yang dilindungi dikarenakan populasiya yang semakin menurun [55].

Gambar 4 secara umum memberikan potensial kerusakan pada substrat dasar perairan di lokasi penelitian, dimana ada sampah umum, rusaknya karang karena dinamit dan jangkar. Perairan di lokasi penelitian (Selat Sempu) merupakan daerah antara, yaitu daerah pertemuan area konservasi (Cagar Alam P. Sempu) dengan daerah pemanfaatan (pelabuhan pendaratan ikan dan wisata), sehingga kemungkinan adanya kerusakan akibat aktifitas manusia dimungkinkan sangat tinggi. [56; 57] menyatakan bahwa efek dari kegiatan SCUBA dari kegiatan wisata adalah terancamnya ekosistem terumbu karang karena perilaku penyelam, seperti kicking, dan berpegangan pada karang. Sampah umum yang ditemukan juga dimungkinkan berasal dari "kiriman" dari daratan yang terbawa dari sungai yang terletak di sebelah barat lokasi penelitian.

Ancaman kerusakan terumbu karang dan Invertebrata yang berada di dalamnya adalah sampah. Ada beberapa kategori tingkat kerusakan terumbu karang, yaitu kategori 1 sampai 3 [8]. Berdasarkan penelitian, kerusakan karang di perairan Sempu termasuk ke dalam kategori 1 atau rendah. Kerusakan tertinggi disebabkan oleh aktivitas perahu/ jangkar dan trash.

Aktifitas yang dapat menyebabkan kerusakan terumbu karang secara fisik adalah kegiatan penyelaman, penambatan kapal dengan sistem jangkar, endapan pecahan karang di dalam sedimen dan pencemaran dari industri termasuk powerplant [38]. Kondisi kerusakan terumbu karang berdampak langsung terhadap hasil tangkapan nelayan tradisional dalam jangka waktu lima tahun [39]. Ada beberapa perilaku yang sering ditemukan di lokasi penelitian, seperti pembuangan limbah plastic, limbah oli, limbah cat, dan limbah domestic kedalam perairan secara langsung. Hal ini terjadi turun temurun dan terjadi secara lama. Melalui kegiatan Reef Check ini, diharapkan dapat mengubah kultur yang telah ada secara perlahan-lahan, sehingga perairan Pulau Sempu dan invertebrata yang berada di dalamnya dapat tetap lestari

Ancaman kerusakan terumbu karang dan Invertebrata yang berada di dalamnya adalah sampah. Ada beberapa kategori tingkat kerusakan terumbu karang, yaitu kategori 1 sampai 3 [8]. Berdasarkan penelitian, kerusakan karang di perairan Sempu termasuk ke dalam kategori 1 atau rendah. Kerusakan tertinggi disebabkan oleh aktivitas perahu/ jangkar dan trash.

Aktifitas yang dapat menyebabkan kerusakan terumbu karang secara fisik adalah kegiatan penyelaman, penambatan kapal dengan sistem jangkar, endapan pecahan karang di dalam sedimen dan pencemaran dari industri termasuk powerplant [38]. Kondisi kerusakan terumbu karang berdampak langsung terhadap hasil tangkapan nelayan tradisional dalam jangka waktu lima tahun [39]. Ada beberapa perilaku yang sering ditemukan di lokasi penelitian, seperti pembuangan limbah plastic, limbah oli, limbah cat, dan limbah domestic kedalam perairan secara langsung. Hal ini terjadi turun temurun dan terjadi secara lama. Melalui 
kegiatan Reef Check ini, diharapkan dapat mengubah kultur yang telah ada secara perlahan-lahan, sehingga perairan Pulau Sempu dan invertebrata yang berada di dalamnya dapat tetap lestari.

\section{KESIMPULAN}

Ditemukan 5 biota indikator pada penelitian ini, yaitu Banded Coral Shrimp, Diadema urchin, Pencil urchin, Collector urchin, dan Kima. Masing-masing biota indikator ditemukan dalam jumlah sedikit. Hal ini memberikan kesimpulan bahwa tingkat kesehatan ekosistem terumbu karang juga kurang bagus. Tingkat kerusakan karang yang terjadi di perairan Pulau Sempu mayoritas disebabkan oleh jangkar kapal, penggunaan bahan peledak untuk menangkap ikan, dan adanya sampah yang menutupi karang. Penelitian ini diharapkan dapat menjadi rujukan penelitian lain mengenai hubungan kelimpahan invertebrata dengan kondisi terumbu karang beserta kondisi lingkungan yang ada di perairan Pulau Sempu.

\section{UCAPAN TERIMAKASIH}

Penelitian ini merupakan hasil dari penelitian Mata Kuliah Selam Keahlian. Penulis berterima kasih kepada berbagai pihak yang telah membantu kegiatan ini: Tim volunteer Reef Check Sempu; Bhakti Alam Sendang Biru; dan UPT P2SKP Pondok Dadap.

\section{DAFTAR PUSTAKA}

[1] Barnes, R. D. "Invertebrate zoology (No. Ed. 5)". WB Saunders company. 1987

[2] Puranik, P., \& Bhate, A. "Animal Forms and Functions: Invertebrate". Sarup \& Sons. 2007

[3] Hutomo, M., Moosa, M.K. "Indonesian Marine and Coastal Biodiversity: Present status". Indian J. Mar. Sci. 34, 88-97. 2005
[4] Zhang, D., Lin, J., \& LeRoy Creswell, R. "Mating behavior and spawning of the banded coral shrimp Stenopus hispidus in the laboratory". Journal of Crustacean Biology, 18(3), 511-518. 1998

[5] Lessios, H. A. "The great Diadema antillarum die-off: 30 years later". Annual review of marine science, 8, 267-283. 2016

[6] Ebert, T. A. "Growth, regeneration, and damage repair of spines of the slatepencil sea urchin Heterocentrotus mammillatus (L.) (Echinodermata: Echinoidea)". 1988

[7] Dworjanyn, S. A., Pirozzi, I., \& Liu, W. "The effect of the addition of algae feeding stimulants to artificial diets for the sea urchin Tripneustes gratilla". Aquaculture, 273(4), 624-633. 2007

[8] Purcell, S. W., Ngaluafe, P., Foale, S. J., Cocks, N., Cullis, B. R., \& Lalavanua, W. "Multiple factors affect socioeconomics and wellbeing of artisanal sea cucumber fishers". PloS one, 11(12), e0165633. 2016

[9] Reef Guide. "Pinkfish Sea Cucumber". https://reefguide.org/pixhtm1/holothuriae dulis1.html. 2016

[10] Reef Guide. "Pineapple Sea Cucumber". https://reefguide.org/pixhtml/pineapples eacucumber1.html. 2016

[11] Chao, S. M. "Revision of Taiwan starfish (Echinodermata: Asteroidea), with description of ten new records". Zoological StudiesTaipei, 38(4), 405-415. 1999

[12] Baeza, J. A., Simpson, L., Ambrosio, L. J.,Mora, N., Guéron, R., \& Childress, M. J. "Active parental care, reproductive performance, and a novel egg predator affecting reproductive investment in the 
Caribbean spiny lobster Panulirus argus". BMC Zoology, 1(1), 6. 2016

[13] Osorio, C. "Charonia tritonis (Linne 1758) en Isla de Pascua (Mollusca: Gastropoda: Cymatiidae)". Rev. Biol. Mar. Oceanog, 26, 75-80. 1991

[14] Roué, M., Darius, H. T., PiCOTs, S., Ung, A., Viallon, J., Gaertner-Mazouni, N., ... \& Chinain, M. "Evidence of the bioaccumulation of ciguatoxins in giant clams (Tridacna maxima) exposed to Gambierdiscus spp. Cells". Harmful algae, 57, 78-87. 2016

[15] Sastrawijaya, A.T. "Pencemaran Lingkungan". PT. Rineka Cipta, Jakarta. 2000

[16] Hair, C., Warren, R., Tewaki, A., Haro, C., \& Phillips, W. "Catching and rearing postlarval cleaner shrimp for the aquarium trade: results from a WorldFish Center project in Solomon Islands". NAGA, WorldFish Center Quarterly, 27(1-2), 42-48. 2004

[17] Vimono, I.B. "Sekilas Mengenai Landak Laut”. J. Oseana XXXII, 37-46. 2007

[18] Toha, A. H. A. "Manfaat bulu babi (Echinoidea), dari sumber pangan sampai organisme hias". Jurnal IlmuIlmu Perairan dan Perikanan Indonesia, 13(1), 77-82. 2016

[19] Habibi, A., Setiasih, N., \& Sartin, J. “A decade of reef check monitoring: Indonesian coral reefs, condition and trends". The Indonesian Reef Check Network, 32. 2007

[20] Kaplan, E. H. "A field guide to southeastern and Caribbean seashores: Cape Hatteras to the Gulf coast, Florida, and the Caribbean (Vol. 36)". Houghton Mifflin Harcourt. 1999

[21] Skomal, G. "Saltwater aquariums for dummies". John Wiley \& Sons. 2011
[22] Belda-Baillie, C. A., Leggat, W., \& Yellowlees, D. "Growth and metabolic responses of the giant clamzooxanthellae symbiosis in a reeffertilisation experiment". Marine Ecology Progress Series, 131-141. 1998

[23] Lucas, J. S. "Giant clams". Current Biology, 24(5), R183-R184. 2014

[24] Soo, P., \& Todd, P. A. "The behaviour of giant clams (Bivalvia: Cardiidae: Tridacninae)". Marine biology, 161(12), 2699-2717. 2014

[25] Aswandy, I. "Sumberdaya Hayati Di Kawasan Pesisir Teluk Kwandang, Sulawesi Utara". Oseana, Majalah Ilmiah Semi Populer Volume XXXII Nomor, 3. 2008

[26] Ardiansyah, A. "Extraction and Oral Suspension Formulation of Sea Cucumber Holothuria scabra as Source of Antioxidants". Oseanologi dan Limnologi di Indonesia, 1(1), 29-37. 2016

[27] Bordbar, S., Anwar, F., \& Saari, N. "High-value components and bioactives from sea cucumbers for functional fooda review". Marine drugs, 9(10), 17611805. 2011

[28] Mahdiana, A., \& Laurensia, S. P. "Status Perikanan Lobster (Panulirus spp.) di Perairan Kabupaten Cilacap". Sains Akuatik, 13(2). 2010

[29] Snyderman, M., \& Wiseman, C. "Guide to marine life: Caribbean, Bahamas, Florida". Aqua Quest Publications, Inc. 1996

[30] Metz, L. "Discovering Starfish". The Rosen Publishing Group. 2011

[31] Luthfi, O. M., Alifia, R., Putri, S. R., Dasi, F. B., Putra, B. A., Permana, D. E., ... \& Sibuea, K. "Pemantauan Kondisi Ikan Karang Menggunakan Metode Reef Check Di Perairan Selat Sempu Malang 
Selatan". Journal of Marine and Aquatic Sciences, 3(2), 171-179. 2017

[32] Hermawan, D. "The Prospective of Sendang Biru Coastal Zone Development for Integrated Fisheries Industry”. Jurnal Protein, 13(2). 2006

[33] Handartoputra, A., Purwanti, F., \& Hendrarto, B. "Penilaian Kerentanan Pantai di Sendang Biru Kabupaten Malang terhadap Variabel Oceanografi berdasarkan Metode CVI (Coastal Vulnerability Index)". Management of Aquatic Resources Journal, 4(1), 91-97. 2015

[34] Watson, S.A. "Giant Clams and Rising CO2: Light may Ameliorate Effects of Ocean Acidification on a Solar-Powered Animal". PloS one, 10(6), p.e0128405. 2015

[35] Bahri, Samsul, Edi Rudi, dan Irma Dewiyanti. "Kondisi terumbu karang dan makro invertebrata di Perairan Ujong Pancu, Kecamatan Peukan Bada, Aceh Besar." DEPIK Jurnal Ilmu-Ilmu Perairan, Pesisir dan Perikanan 4.1 (2015).

[36] Daruwedho, H., Sasmito, B., Janu A., F. "Analisis Pola Arus Laut Permukaan Perairan Indonesia dengan Menggunakan Satelit Altimetri Jason-2 Tahun 2010-2014”. J. Geod. Undip 5, 14. 2016

[37] Wibawa, I.G.N.A. and Luthfi, O.M. "Kualitas Air pada Ekosistem Terumbu Karang di Selat Sempu, Sendang Biru, Malang”. Jurnal Segara, 13(1). 2017

[38] Osborne, P. L. "Tropical ecosystems and ecological concepts". Cambridge University Press. 2000

[39] Samuel, P. D., Raka, D. G., \& Yanuwiyadi, B. "Species and Abundance of Sea Urchins (Diadematidae) on Different
Environmental

Pressure

Conditions". Journal of Tropical Life Science, 7(2), 146-150. 2017

[40] Speight, M. R., \& Henderson, P. A. "Marine ecology: concepts and applications". John Wiley \& Sons. 2013

[41] Krohne, D. T. "General ecology". Brooks/Cole Publishing Company. 2001

[42] Kartini, H.A., Kurniawan, N. "Struktur Komunitas Vertebrata dan Invertebrata Air pada Petak Sawah Organik di Kecamatan Lawang, Kabupaten Malang”. Biotropika 1, 160-165. 2013

[43] Fuji, A. "Ecological studies on the growth and food consumption of Japanese common littoral sea urchin, Strongylocentrotus intermedius (A. Agassiz)". Memoirs of the Faculty of Fisheries Hokkaido University, 15(2), pp.83-160. 1967

[44] Yulianto, A.R. "Pemanfaatan Bulu Babi secara Berkelanjutan pada Kawasan Padang Lamun". Program Studi Ilmu Lingkungan Program Pascasarjana, Universitas Indonesia. Thesis (Tidak dipublikasikan). 2012

[45] Sukmara, A., Siahainenia, A.J. and Rotinsulu, C. "Panduan Pemantauan Terumbu Karang Berbasis-Masyarakat dengan Metode Manta Tow". Coastal Resources Center, Jakarta. 2001

[46] Haruddin, A., Edi, P., \& Budiastuti, S. "Dampak Kerusakan Ekosistem Terumbu Karang Terhadap Hasil Penangkapan Ikan oleh Nelayan secara Tradisional di Pulau Siompu, Kabupaten Buton, Provinsi Sulawesi Tenggara". Jurnal Ekosains, 3(3), 2941. 2011

[47] Luthfi, O. M., \& Jauhari, A. “Assesmen Kondisi Fisika-Kimia Oseanografi Perairan Pulau Sempu Malang Selatan Sebagai Parameter Penentuan Lokasi 
Pembuatan Taman Karang". Prosiding PIT X ISOI, 1(1). 2013

[48] Chockley, B. R., \& Mary, C. M. S. "Effects of Body Size on Growth, Survivorship, and Reproduction in the Banded Coral Shrimp, Stenopus hispidus". Journal of crustacean biology, 23(4), 836-848. 2003

[49] Voss, G. L. "Seashore life of Florida and the Caribbean". Courier Corporation. 2013

[50] Wilkinson, C. R. "Global and local threats to coral reef functioning and existence: review and predictions". Marine and Freshwater Research, 50(8), 867-878. 1999

[51] McClanahan, T. R. "Effects of fisheries closures and gear restrictions on fishing income in a Kenyan coral reef". Conservation Biology, 24(6), 1519-1528. 2010

[52] Carpenter, R. C. "Invertebrate predators and grazers. Life and death of coral reefs". Chapman and Hall, New York, 198-229. 1997
[53] Santhanam, R. "Nutritional marine life". CRC Press. 2014

[54] Hill, R. W., Armstrong, E. J., Florn, A. M., Li, C., Walquist, R. W., \& Edward, A. "Abundant betaines in giant clams (Tridacnidae) and western Pacific reef corals, including study of coral betaine acclimatization”. Marine Ecology Progress Series, 576, 27-41. 2017

[55] Sumich, J. L., \& Morrissey, J. F. "Introduction to the Biology of Marine Life". Jones \& Bartlett Learning. 2004

[56] Dewi, I. N., \& Hayati, N. "Etnoekologi Masyarakat Sekitar Taman Nasional Taka Bonerate dalam Pemanfaatan Kima Lubang (Tridacna crocea) dan Ikan Malaja (Siganus canaliculatus)". Jurnal Penelitian Kehutanan Wallacea, 3(2), 139-149. 2014

[57] Medio, D., Ormond, R.F.G. and Pearson, M. "Effect of briefings on rates of damage to corals by scuba divers". Biological Conservation, 79(1), pp.91-95. 1997 